\title{
The Crystal and Molecular Structure of Indium and Iron(III) Complexes with 1-(2-Thienyl)-4,4,4-trifluoro-1,3-butanedione
}

\author{
H. SOLING
}

Chemistry Department B, Technical University of Denmark, DK-2800 Lyngby, Denmark

Single crystals of the title compounds, In(TTA) and $\mathrm{Fe}(\mathrm{TTA})_{3}$, have been investigated by X-ray diffractometry. The compounds are isostructural In(TTA) $)_{3}: a=8.803(15) \AA, b=17.67(3) \AA$, $c=19.63(4) \AA, \beta=110.2(1)^{\circ}$. Fe(TTA $)_{3}: 8.865(9)$ $\AA, b=17.46(2) \AA, c=19.69(2) \AA, \beta=110.8(1)^{\circ}$. Space group $P 2_{1} / c$. The structures were refined to $R=0.069$ and 0.078 , respectively. The unit cell contains two pairs of meridional-tris- $\beta$ diketonate complexes centered on the special positions $\frac{1}{2}, 0,0$ and $\frac{1}{2}, \frac{1}{2}, \frac{1}{2}$. The metal atom is at the center of gravity of the six coordinating oxygen atoms, which form the apices of a slightly deformed octahedron. The average In - $\mathrm{O}$ distance is $2.13(2) \AA$, the $\mathrm{Fe}-\mathrm{O}$ distance is $1.99(2) \AA$. Contrary to other tris- $\beta$-diketonates the two $C-C$ bonds of the chelate ring are of unequal length, the $\mathrm{C}-\mathrm{C}$ bond closest to the $\mathrm{CF}_{3}$ group being the shorter. Fluorine atoms apart, each ligand may roughly be represented by a plane pivoted around an edge of the coordination polyhedron.

The crystal structure analysis, reported in this paper, is the second of a current series of structure investigations ${ }^{1}$ of metal compounds of 1-(2-thienyl)-4,4,4-trifluoro-1,3-butanedione, (trivial name thenoyltrifluoracetone). The structure formula of this unsymmetric $\beta$-diketone, henceforth designated HTTA, is shown in Fig. 1.

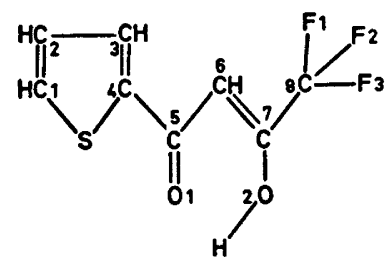

Fig. 1. Structure formula of 1-(2-thienyl)-4,4,4trifluoro-1,3-butanedione, displaying the labelling scheme.

Acta Chem. Scand. A 30 (1976) No. 3
The compounds In(TTA), and $\mathrm{Fe}(\mathrm{TTA})_{3}$, which are the topics of this paper, are isostructural.

\section{EXPERIMENTAL}

Preparation and analysis

In $(T T A)_{3} 6.6 \mathrm{~g}$ of $\mathrm{InCl}_{3}(\mathrm{BDH})$ was dissolved in $130 \mathrm{ml}$ of $50 \%$ ethanol, (v/v). $15.9 \mathrm{~g}$ of the $\beta$-diketone (Merck), freshly sublimed in vacuo, were dissolved in $320 \mathrm{ml}$ of $50 \%$ ethanol and neutralized with ammonia. The former solution was slowly poured into the latter under vigor. ous stirring. The stirring was continued for half an hour, then the precipitation was completed by addition of $450 \mathrm{ml}$ of water. The white, microcrystalline raw product was washed with water and dried in the air. Colourless, tabular crystals were grown from a solution of the raw product in nitromethane. The melting point, determined on a microscope hot stage (Mettler FP52/5), was $164.6 \pm 0.8^{\circ} \mathrm{C}$. After destruction of the complex with concentrated nitric acid, indium was determined by microtitration with EDTA according to Schwarzenbach. ${ }^{2}$ (Found: In 14.68. Calc. for $\operatorname{In}\left(\mathrm{C}_{8} \mathrm{H}_{4} \mathrm{~F}_{3} \mathrm{O}_{2} \mathrm{~S}\right)_{3}$ : 14.75).

$\mathrm{Fe}(T T A)_{3}$ was prepared as described by Berg and Truemper. ${ }^{3}$ Single crystals were grown from a solution of the raw material in a $50 \%(\mathrm{v} / \mathrm{v})$ mixture of diethylether and cyclohexane. The well-developed, garnet red, prismatic crystals melt at $162.6 \pm 0.5^{\circ} \mathrm{C}$ on the hot stage microscope; m.p. lit. ${ }^{\circ} 159-160^{\circ} \mathrm{C}$. Iron was determined by microtitration with EDTA $^{2}$ after appropriate destruction of the complex. (Found: Fe 7.78. Calc. for $\left.\mathrm{Fe}\left(\mathrm{C}_{8} \mathrm{H}_{4} \mathrm{~F}_{3} \mathrm{O}_{2} \mathrm{~S}\right)_{3}: 7.76\right)$.

\section{Collection and treatment of intensity data}

Intensity data were collected by means of a semi-automatic two-circle diffractometer, run in the $\omega$-scan mode. Net intensities were con- 
verted to relative structure factors by application of the usual Lorentz and polarization corrections.

$\operatorname{In}(T T A)_{3}$. Monochromatized (graphite) $M o K \alpha$ radiation $(\lambda=0.71069 \AA)$ was used to measure the reflections from all unique planes in the $\sin \theta / \lambda$ range from 0.06 to $0.6 \AA^{-1}$. Two different crystals had to be used. During the scanning of the $h 8 l$ zone, the first crystal became opaque, and its reflecting power decreased more than $10 \%$ within a few hours. A second crystal sufficed for the remainder of the data collection. For scaling purposes the $h 0 l$ reflections of the second crystal were also measured. The dimensions of the two crystals were $0.250 \times 0.060 \times 0.375 \mathrm{~mm}^{2}$ and $0.375 \times$ $0.070 \times 0.400 \mathrm{~mm}^{3}$, respectively. Since the platey crystals were mounted with their shortest dimension (the $b$-axis) along the direction of the Weissenberg spindle, corrections for absorption "were made. A Gaussian grid of 864 sample points was found suitable. Each $F_{0}$ was assigned a standard deviation based on counting statistics. Reflections with $F_{0}<3 \sigma\left(F_{0}\right)$ were rejected, leaving 2759 reflections for the struc. ture analysis, i.e. more than 6 observations per adjustable parameter.

$F e(T T A)_{2 .}$ The $\sin \theta / \lambda$ range was 0.06 to $0.45 \AA^{-1}$, (LiF-monochromator). No corrections were made for absorption. The yield of $F_{0}<3 \sigma\left(F_{0}\right)$ was 1178 , i.e. approximately 5 observations per refined parameter. (Fe and F atoms only were assigned anisotropic tem. perature parameters).

\section{CRYSTAL DATA}

$\mathrm{In}\left(\mathrm{C}_{8} \mathrm{H}_{4} \mathrm{~F}_{3} \mathrm{O}_{2} \mathrm{~S}\right)_{3} \quad(\mathrm{FW}=778.3) \quad$ and $\mathrm{Fe}\left(\mathrm{C}_{8} \mathrm{H}_{4} \mathrm{~F}_{3} \mathrm{O}_{2} \mathrm{~S}\right)_{3} \quad(\mathrm{FW}=719.4)$ both crystallize in the space group $P 2_{1} / c$ (No. 14). Unit cell dimensions were determined from several in. dependent precession photographs.

$\operatorname{In}(T T A)_{s}: a=8.803(15) \AA, b=17.67(3) \AA$, $c=19.63(4) \AA, \beta=110.2(1)^{\circ}$, at $22{ }^{\circ} \mathrm{C}$. Volume of the cell $=2867 \AA^{3} . F(000)=1528 . D_{x}(\mathrm{Z}=4)=$ $1.788 \mathrm{~g} \mathrm{~cm}^{-3}, \quad D_{m}$ (flot. $)=1.788(5) \mathrm{g} \mathrm{cm}^{-3}$. $\mu(\mathrm{MoKa})=11.3 \mathrm{~cm}^{-1}$.

$F e(T T A)_{3}: a=8.865(9) \AA, b=17.46(2) \AA$, $c=19.69(2) A, \beta=110.8(1)^{\circ}$, at $22{ }^{\circ} \mathrm{C}$. Volume of the cell $=2848 \AA^{3} . F^{\prime}(000)=1436 . D_{x}(Z=4)=$ $1.678 \mathrm{~g} \mathrm{~cm}$ co $D_{m}$ (flot.) $=1.675(5) \mathrm{g} \mathrm{cm}^{-1}$. $\mu(\operatorname{MoK} \alpha)=8.60 \mathrm{~cm}^{-1}$.

\section{SOLUTION AND REFINEMENT OF THE STRUCTURES}

In $(T T A)_{3}$. The structure was solved for all non-hydrogen atoms by application of the heavy atom method. At the later stages of
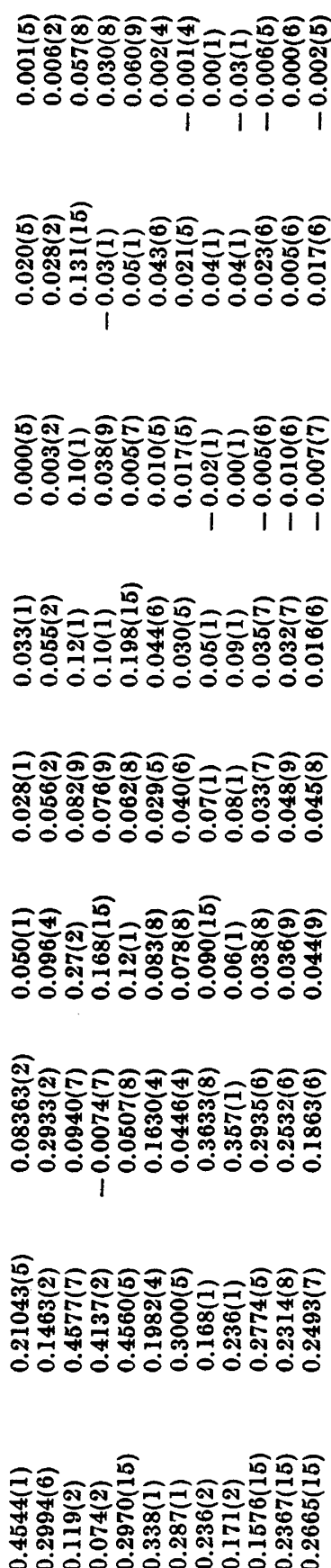

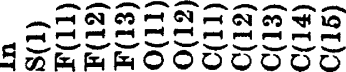

Acta Chem. Scand. A 30 (1976) No. 3 


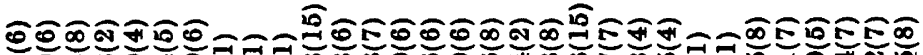

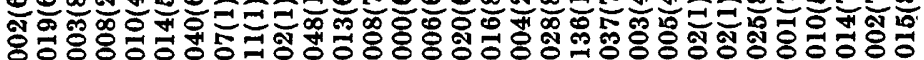
0000000070000000000000000000000 i 111111110000000000000000011111

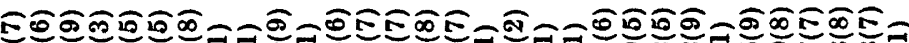

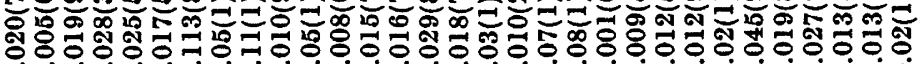
0000000000000000000000000000000

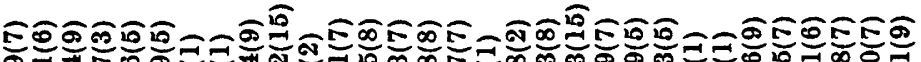

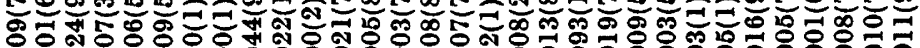

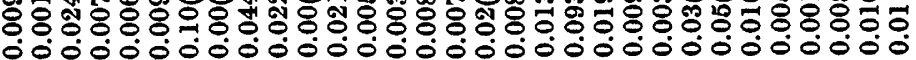

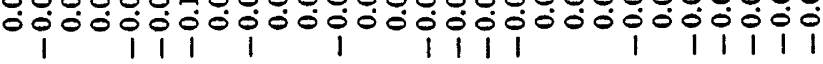

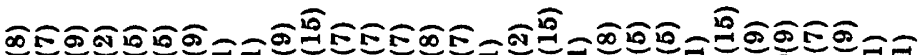

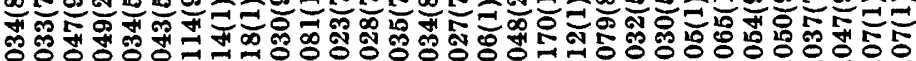

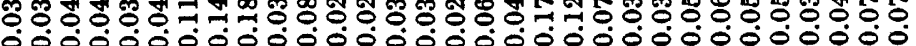

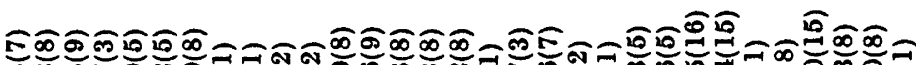

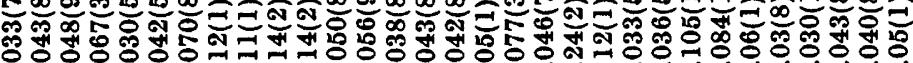
0000000001000000000000000000000

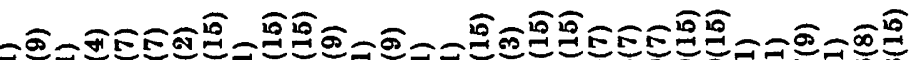

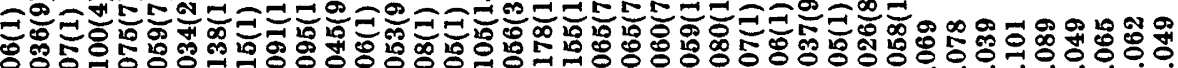

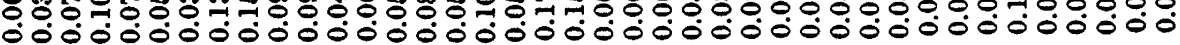

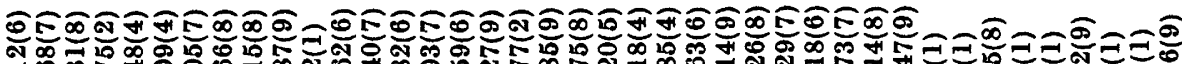

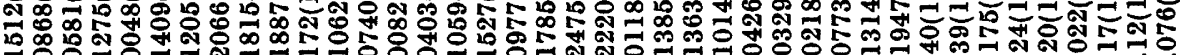

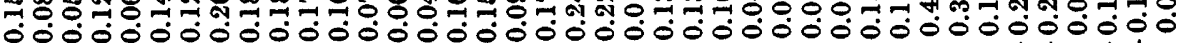
i 111110001 i 1111

हैं

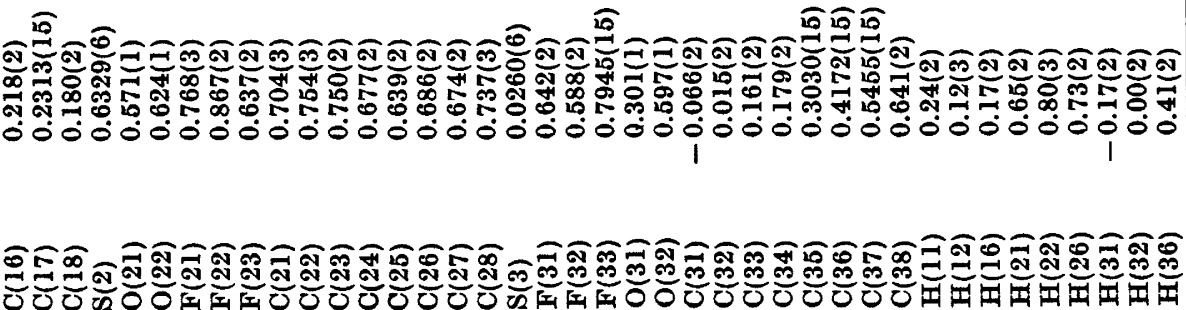

Acta Chem. Scand. A 30 (1976) No. 3 
refinement an empirical weight function, $w \mathbf{t}=$ $\left(5.0+0.0140 F_{0}\right)^{-\frac{1}{2}}$, was used. When the refinement was nearly completed, the sites of the hydrogen atoms, except those attached to the $\mathrm{C}(3)$ atoms, could be localized on a Fourier difference map. Each hydrogen atom was assigned an (invariant) isotropic temperature factor corresponding to that of the carrier atom. A few more cycles of least squares calculations brought the refinement to a conclusion, where all shifts were less than $1 / 10$ of the estimated standard deviation. The final $R$ value was 0.069 , and the error of fit quotient was 1.15 .

$F e(T T A)_{3}$. The structure was solved and refined for all non-hydrogen atoms, the indium compound being used as a starting model. $w=14.1 / F_{\text {o }}$ maximum allowed $w=0.1$. The refinement terminated at $R=0.078$. The error of fit quotient was 1.09 .

Atomic form factors for the neutral atoms were used throughout. For indium the form factors were those given by Cromer and Waber. ${ }^{5}$ The other form factors, as well as corrections for the anomalous dispersion of $\mathrm{In}$ and $\mathrm{Fe}$, were taken from International Tables for $X$-Ray Crystallography. Fractional coordinates and thermal parameters of the observed atoms are listed in Tables 1 and 2. Lists of observed and calculated structure factors may be obtained from this institute.

All crystallographic calculations have been performed with the X-RAY program system edited by Stewart.' The stereo drawing Fig. 2 has been made by means of the ORTEP II program of Johnson. ${ }^{8}$

\section{RESULTS AND DISCUSSION}

Both structures consist of pairs of meridional tris- $\beta$-diketonate molecules, centered around the special positions $\frac{1}{2}, 0,0$ and $\frac{1}{2}, \frac{1}{2}, \frac{1}{2}$ (Fig. 2). The separation of the two enantiomorphous molecules in terms of the metal to metal distance is $8.28 \AA$ for $\operatorname{In}(T T A)_{3}$ and $8.22 \AA$ for $\mathrm{Fe}(\mathrm{TTA})_{3}$. The next shortest metal to metal distance is the $a$ translation.

The metal atom is almost exactly at the common center of gravity of the six coordinating oxygen atoms, which form the apices of a slightly deformed octahedron. Metal to oxygen distances, oxygen to oxygen distances and some
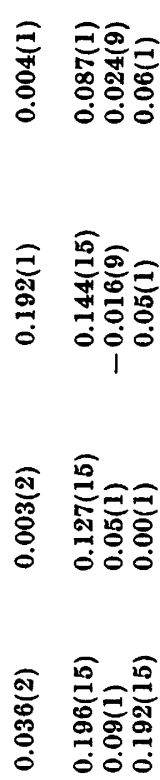

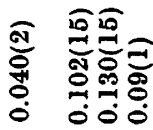
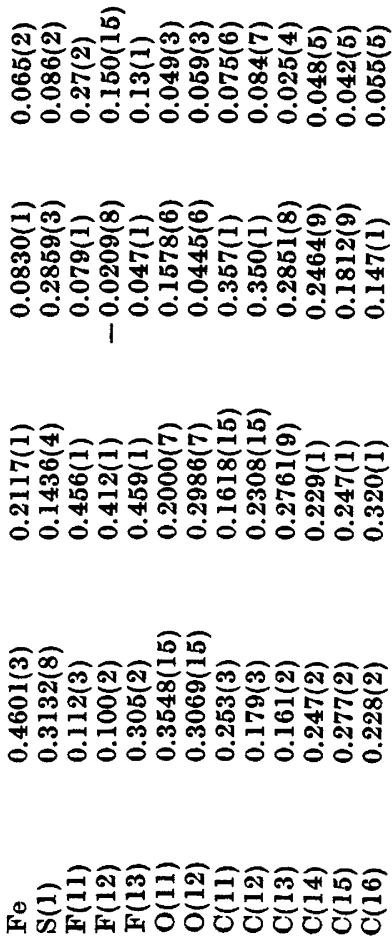

Acta Chem. Scand. A 30 (1976) No. 3 
통형

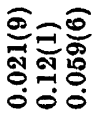

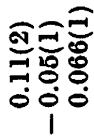

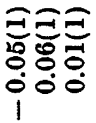

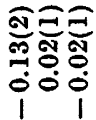

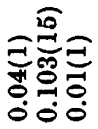

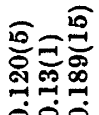

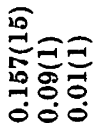

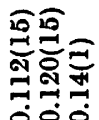

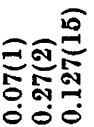

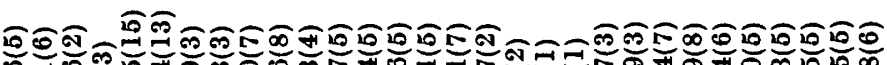

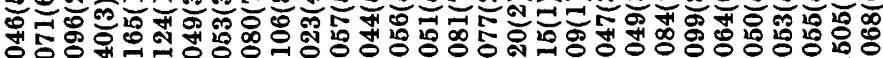
00000

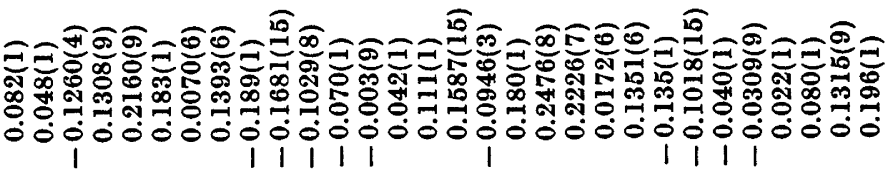

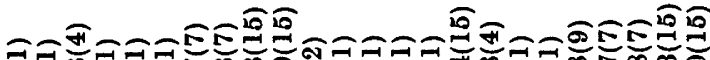

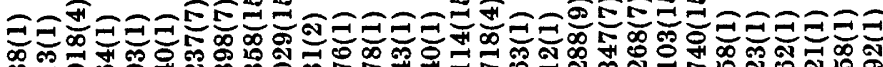

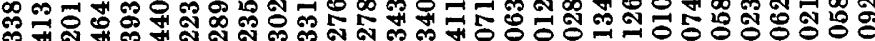
ஸ் 000000000000111

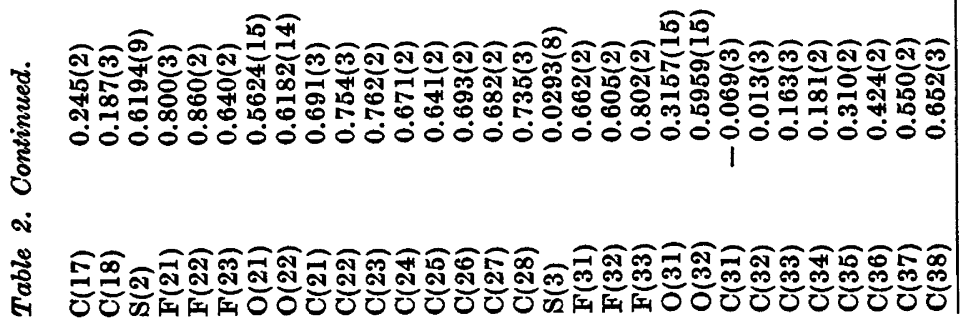

Acta Chem. Scand. A 30 (1976) No. 3 

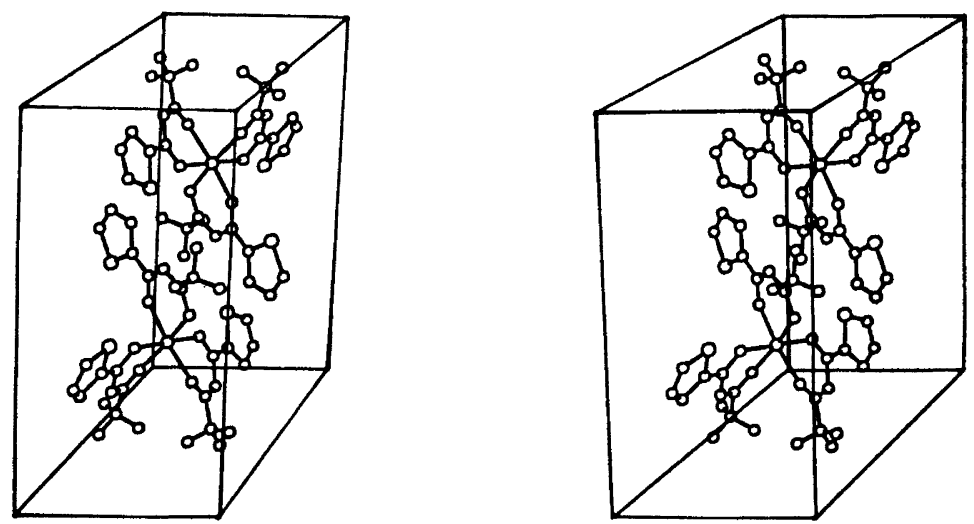

Fig. 2. Stereo drawing of one enanthiomorphous pair of $\operatorname{In}(\mathrm{TTA})_{3}$ molecules centered around $\frac{1}{2}, \frac{1}{2}, \frac{1}{2}$. The $b$ axis is pointing upward.
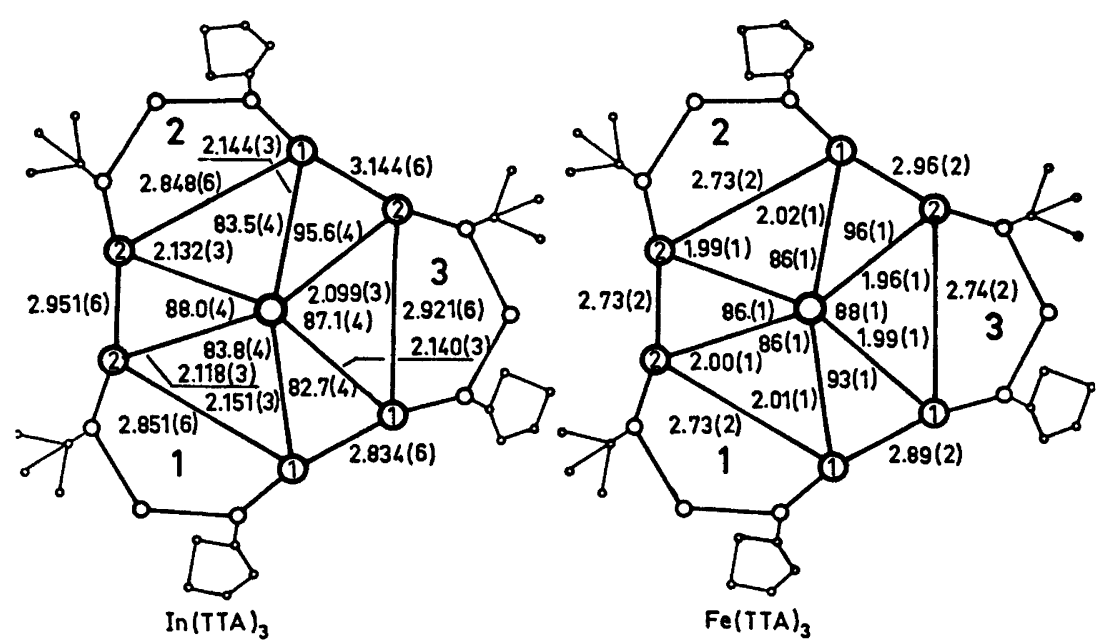

Fig. 3. Schematic representation of the complexes showing distances and (some) angles of the octahedron of coordination. Standard deviations are in parentheses.

oxygen-metal-oxygen bond angles are shown in Fig. 3.

The average $\mathrm{Fe}-\mathrm{O}$ distance is $1.99(2) \AA^{*}$. The same average distance $1.992(6) \AA$, has been found in ferric tris-acetylacetonate.' Also the average oxygen to oxygen "bite" distances of the chelate rings are virtually the same in the two ferric compounds, viz. 2.740(15) $\AA$ in the present compound and $2.732(2) \AA$ in the acetylacetonate. The average In $-O$ distance is $2.13(2) \AA$. No structure determinations of

* Standard deviations of averages quoted in this section are semple deviations. $\boldsymbol{\beta}$-diketonates or similar compounds have been reported as yet. In $-O$ distances ranging from $\sim 2.1$ to $\sim 2.2 \AA$ have been found in some purely inorganic compounds, e.g. 2.171(8) $\AA$ in $\operatorname{In}(\mathrm{OH})_{3}{ }^{10}$.

As far as bond lengths and bond angles of the ligand are concerned the compounds investigated resemble each other closely. Average values for each compound are listed in Tables 3 and 4. The results compare well with those found for the Cs salt ${ }^{1}$ and with those reported for $\mathrm{NH}_{4} \operatorname{Pr}(\mathrm{TTA})_{4} \cdot 2 \mathrm{H}_{2} \mathrm{O} .11$

A certain lack of regularity of the chelate ring is expected, due to the electronegative

Acta Chem. Scand. A 30 (1976) No. 3 
Table 3. In(TTA $)_{3}$ and $\mathrm{Fe}(\mathrm{TTA})_{3}$. Average lengths, in $\AA$, of chemically equivalent bonds. The standard deviations (in parentheses) have been calculated from the formula $\sigma_{l}=\left[\sum_{i}\left(l_{i}-\bar{l}\right)^{2} /(n-1)\right]^{\mathbf{t}}$. The typical standard deviation of individual bonds as estimated from the least squares refinement is $0.02 \AA$ for $\operatorname{In}(\mathrm{TTA})_{3}$ and $0.03 \AA$ for $\mathrm{Fe}(\mathrm{TTA})_{3}$.

\begin{tabular}{|c|c|c|c|c|}
\hline Atoms & $\begin{array}{l}\operatorname{In}(\mathrm{TTA})_{\mathbf{3}} \\
\text { Average }\end{array}$ & Range & $\begin{array}{l}\mathrm{Fe}(\mathrm{TTA})_{3} \\
\text { Average }\end{array}$ & Range \\
\hline $\begin{array}{l}S-C(1) \\
S-C(4) \\
C(1)-C(2) \\
C(2)-C(3) \\
C(3)-C(4)\end{array}$ & $\begin{array}{l}1.688(9) \\
1.709(15) \\
1.32(2) \\
1.41(2) \\
1.44(2)\end{array}$ & $\begin{array}{l}0.015 \\
0.032 \\
0.04 \\
0.03 \\
0.08\end{array}$ & $\begin{array}{l}1.70(2) \\
1.68(3) \\
1.34(4) \\
1.43(7) \\
1.49(5)\end{array}$ & $\begin{array}{l}0.04 \\
0.05 \\
0.07 \\
0.12 \\
0.09\end{array}$ \\
\hline $\begin{array}{l}C(4)-C(5) \\
C(5)-C(6) \\
C(6)-C(7) \\
C(7)-C(8)\end{array}$ & $\begin{array}{l}1.45(1) \\
1.41(3) \\
1.35(3) \\
1.52(1)\end{array}$ & $\begin{array}{l}0.02 \\
0.06 \\
0.05 \\
0.02\end{array}$ & $\begin{array}{l}1.43(1) \\
1.430(5) \\
1.38(1) \\
1.61(3)\end{array}$ & $\begin{array}{l}0.03 \\
0.01 \\
0.03 \\
0.05\end{array}$ \\
\hline$C(8)-F$ & $1.29(2)$ & 0.05 & $1.28(4)$ & 0.11 \\
\hline $\begin{array}{l}C(5)-O(1) \\
C(7)-O(2)\end{array}$ & $\begin{array}{l}1.27(1) \\
1.28(2)\end{array}$ & $\begin{array}{l}0.03 \\
0.04\end{array}$ & $\begin{array}{l}1.26(2) \\
1.269(5)\end{array}$ & $\begin{array}{l}0.05 \\
0.009\end{array}$ \\
\hline $\begin{array}{l}\mathrm{C}(1)-\mathrm{H}(1) \\
\mathrm{C}(2)-\mathrm{H}(2) \\
\mathrm{C}(6)-\mathrm{H}(6)\end{array}$ & $\begin{array}{l}0.93(6) \\
0.93(15) \\
0.99(4)\end{array}$ & $\begin{array}{l}0.10 \\
0.32 \\
0.11\end{array}$ & & \\
\hline
\end{tabular}

Table 4. In(TTA) $)_{3}$ and Fe(TTA) $)_{3}$. Average bond angles, in degrees. The standard deviations (in parentheses) have been calculated from the formula $\sigma_{\mathrm{a}}=\left[\sum_{i}\left(a_{i}-\bar{a}\right)^{2} /(n-1)\right]^{\mathbf{t}}$. In most cases the standard deviation of the individual angles as estimated from the least squares refinement is 1 or 2 degrees.

\begin{tabular}{|c|c|c|c|c|}
\hline Atoms & $\begin{array}{l}\text { In(TTA) } \\
\text { Average }\end{array}$ & Range & $\begin{array}{l}\mathrm{Fe}(\mathrm{TTA})_{3} \\
\text { Average }\end{array}$ & Range \\
\hline$C(1)-S-C(4)$ & $92.2(3)$ & 0.6 & $95(2)$ & 3.9 \\
\hline$s-C(1)-C(2)$ & $112(1)$ & 2.7 & $110(2)$ & 2.3 \\
\hline$C(1)-C(2)-C(3)$ & $115.9(7)$ & 2.3 & $118(3)$ & 5.0 \\
\hline $\mathrm{C}(2)-\mathrm{C}(3)-\mathrm{C}(4)$ & $108(1)$ & 2.4 & $107(3)$ & 5.2 \\
\hline$C(3)-C(4)-S$ & $111(1)$ & 2.4 & $111(4)$ & 6.9 \\
\hline$s-C(4)-C(5)$ & $119(1)$ & 1.7 & $120(3)$ & 4.2 \\
\hline$C(3)-C(4)-C(5)$ & $130(2)$ & 3.1 & $129(3)$ & 6.1 \\
\hline$C(4)-C(5)-C(6)$ & $120(1)$ & 2.1 & $120(2)$ & 2.8 \\
\hline$C(5)-C(6)-C(7)$ & $125(1)$ & 2.0 & $120(2)$ & 2.5 \\
\hline$C(6)-C(7)-C(8)$ & $117.4(4)$ & 0.8 & $117(2)$ & 3.7 \\
\hline$O(1)-C(5)-C(4)$ & $116(2)$ & 3.0 & $118(1)$ & 2.3 \\
\hline$O(1)-C(5)-C(6)$ & $123.7(9)$ & 1.6 & $123(2)$ & 3.9 \\
\hline $\mathrm{O}(2)-\mathrm{C}(7)-\mathrm{C}(8)$ & $118.8(7)$ & 1.4 & $114(2)$ & 3.1 \\
\hline$O(2)-C(7)-C(6)$ & $130.9(6)$ & 1.1 & $133(6)$ & 9.8 \\
\hline$F-C(8)-C(7)$ & $113(2)$ & 6.9 & $114(3)$ & 8.0 \\
\hline$F-C(8)-F$ & $105(2)$ & 5.3 & $104(4)$ & 10.9 \\
\hline
\end{tabular}

Acta Chem. Scand. A 30 (1976) No. 3 
Table 5. Comparison of chelate $\mathrm{C}-\mathrm{C}$ bond lengths $(\AA)$ in some TTA compounds.

\begin{tabular}{llll}
\hline Compound & $\mathrm{C}(5)-\mathrm{C}(6)$ & $\mathrm{C}(6)-\mathrm{C}(7)$ & Ref. \\
\hline CsTTA & $1.427(9)$ & $1.380(8)$ & 1 \\
mer-Fe(TTA) & $1.430(5)$ & $1.38(1)$ & present work \\
mer-In(TTA) $_{3}$ & $1.41(3)$ & $1.35(3)$ & present work \\
fac-Cr(TTA) $_{3}$ & $1.406(6)$ & $1.363(8)$ & unpubl. \\
Average $^{a}$ & $1.418(7)$ & $1.367(8)$ & \\
Weighted $^{\text {Average }}{ }^{a}$ & $1.414(4)$ & $1.370(5)$ & \\
\hline
\end{tabular}

a Based on individual observations and standard deviations from the least squares refinement.

character of the terminal $\mathrm{CF}_{3}$ group. The data collected in Table 5 suggest, that the $C(6)-C(7)$ bond is shorter than the $C(5)-C(6)$ bond. This is supported by statistical tests. ${ }^{12}$ The pooled set of observed $\mathrm{C}(5)-\mathrm{C}(6)$ distances show no significant differences, (5\% level). The same is true for the set of $\mathrm{C}(6)-\mathrm{C}(7)$ distances. The difference between the averages of the sets, however, is highly significant, (0.5\% level).

The essential features of the molecular conformation are visible on the stereo drawing Fig. 2. The non-hydrogen atoms of each thiophene group are coplanar ( $5 \%$ level). Roughly, each ligand may be represented by a plane defined by the five atoms $\mathrm{C}(4)$ through $\mathrm{C}(8)$. The standard deviation from the plane of the atoms defining it is $\sim 0.04 \AA$. The pivoting of the ligand plane around the $O(1)-O(2)$ line is a well-known characteristic of $\beta$-diketonate complexes.

The conformation of the two ligands, facing each other in Fig. 2, deviates slightly from that of the other four. The rotation $\left(\sim 25^{\circ}\right)$ of the $\mathrm{CF}_{3}$ group around the $\mathrm{C}(7)-\mathrm{C}(8)$ bond is distinct.

In keeping with the high volatility of the $\beta$-diketonates, ${ }^{13}$ intermolecular distances less than $0.2 \AA+$ sum of van der Waals radii are scarce. No obvious pattern of contacts can be disentangled.

\section{REFERENCES}

1. Soling, H. Acta Chem. Scand. A 29 (1975) 523.

2. Schwarzenbach, G. Die komplexometrische Titration, Ferdinand Enke, Stuttgart 1956.
3. Berg, E. W. and Truemper, J. T. J. Phys. Chem 64 (1960) 487.

4. Coppens, B., Leiserowitz, L. and Rabinovich, D. Acta Crystallogr. 18 (1965) 1035.

5. Cromer, D. T. and Waber, J. T. Acta Crystallogr. 18 (1965) 104.

6. International Tables for X-Ray Crystal. lography, Vol. III, Kynoch Press, Birmingham 1962.

7. X-RAY Program System for X-Ray Crystallography 1972, Computer Science Center, University of Maryland.

8. Johnson, C. K. ORTEP, Report ORNL 3794, Oak Ridge National Laboratory, Oak Ridge 1965.

9. Iball, J. and Morgan, C. H. Acta Crystallogr. 23 (1967) 239.

10. Christensen, A. N., Grønbæk, R. and Rasmussen, S. E. Acta Chem. Scand. 18 (1964) 1261.

11. Lalancette, R. A., Cefola, M., Hamilton, W. C. and La Placa, S. J. Inorg. Chem. 6 (1967) 2127.

12. Hamilton, W. C. Statistics in Physical Sciences, The Ronald Press Company, New York 1964.

13. Berg, E. W. and Reed, K. P. Anal. Chim. Acta 42 (1968) 207.

Received September 2, 1975. 